\title{
The Representation of Human and Nature Relations in the Spell of "Poan Dorong Dopeq"
}

\author{
Nurul Khasanah ${ }^{*}$ and Nurhayati \\ Linguistics Department, Faculty of Humanities, Diponegoro University Semarang, Indonesia
}

\begin{abstract}
Kedang communities in East Nusa Tenggara Province living in the foothills of Uyelewun Mountain have a close relation with nature to fulfil the needs of food, homes, and economy. Because nature provides everything for them, they are appreciate and protect the natural environment as well as possible. They always ask permission from Uhe ria ari baraq and Nature to bless them when carrying out the ritual of Poan dorong dopeq or the tradition of migration. This study aims to discuss how is the representation of human relations with nature in the spell of poan dorong Dopeq. In this case, an ethnograpic perspective is used to uncover both aspects. The spell data listed is secondary data obtained from Pos Kupang of November $24^{\text {th }} 2019$ edition. In addition, researcher also conducted interviews with native speaker and socially prominent of Kedang. The results show that the relations between humans and nature in Poan dorong Dopeq spell is clearly illustrated. Several spells mention the parable through staple food, geographical location, and natural situation of the community. Based on ethnograpic Perspective, this spell is a compulsory component in the ritual of poan dorong dopeq and must be spoken by a Molan to request blessing and prayer to the surrounding nature.
\end{abstract}

Keywords : Representation, Human and Nature, Relations, Spell of Poan Dorong Dopeq

\section{Introduction}

Research on communication ethnography carried out by Manafe, discussed one of the rituals in East Nusa Tenggara province. The ritual explained the behavior of surrounding society that is close to his nature and creator. Antoni Pah Meto, the shaman, recited spell to represent Timorese people gratitude and happiness [1]. Another research in the eastern part of Indonesia was conducted by Peinina about the meaning of Rion-rion and Orom Sasadu ritual in west Halmahera. Sahu Jio Tala'i Padusua tribe is interpreted as a cultural identity, has historical significance, and is a symbol of staple food. This ritual is to show how close are people surrounding north Maluku to their nature, love their earth, and their harvest [2].

* Corresponding author: nurulrul1108@gmail.com 
Based on those two explanations above, it can be inferred that natural and cultural treasures are very abundant.

Indonesia's cultural treasures are very rich and become such an extraordinary thing for people across the globe. Physically, Indonesia's treasures can be recognized from its soil fertility rate as a proverb saying, "Indonesia is a land of paradise, wooden sticks and stones can be plants". But apparently Indonesia's treasures are not just about that, they have a lot of various cultures and traditions. There are 250 million people spread throughout 34 provinces in Indonesia which has varied tribes and cultures each. Among hundreds of tribe in Indonesia, one of it is Kedang tribe located in Lembata regency, East Nusa Tenggara. Kedang tribe is a tribe living in the foothills of Uyelewun Mountain. Kedang's natural environment is still in the form of grasslands, some shrubs and forests. Therefore, the life of Kedang people could not be separated from the mountain and natural environment around them.

There is still a very thick felt of the term "jinxed and misfortune" in Indonesian culture. Not a few Indonesians from different ethnic backgrounds agree with the existence and reality of that term. It is like everything that happen in nature is a sign of something, especially when there is perceived irregularity on it. Likewise, the understanding people of Kedang have, they still believe in a sign of misfortune that can later lead them into disasters. Yet, although a large majority of Indonesian people believe it, but the actions they take after agreeing to this phenomenon is different, some just leave it alone with the reason that it has become destiny, some strengthen their prayers and worships, some does a tribal ceremony, and Kedang people are the ones who perform traditional ceremonies as their solution to face the signs of disasters.

One of the ritual is Poan Dorong Dopeq; a migration ceremony frequently performed by Kedang people. Usually, the migration will be carried out when there are signs of disasters such as successive and unnatural deaths (todi bita hen mateq), hunger (owan mu'u mayaq wei), prolonged illness (molan kuq lan neq), crop failures, and unfriendly situation of hostile nature (uhe auq nitu niwang dotan paleq, ele ling kehe lei ale). Those all makes sense since we know that Kedang people often live around the foothills of the mountain. Its area is vulnerable to live in due to its potential of volcanic eruption, or perhaps the most frequently encountered; the landslide. Therefore, Poan Dorong Dopeq ritual is performed to bless their migration and to hope their new place would be better. That ritual has several ways to do and spells to recite. The existence of the spell itself certainly attracts the researcher in the terms of the language used; Kedang language. It becomes a big a question for the researcher about what does the spell consist of, what the meaning of every sentences in it, and how can the sentence be correlated to their hopes and goals, and how does Poan Dorong Dopeq and its spells correlated to the natural environment.

Explanations regarding the rituals performed in human life are given byMulyana, throughout their lives, human experiencing several rituals, from birth to death. Each region has their own respective rituals, in which there are unique rituals, these uniqueness can arise from various aspects, such as verbal and non-verbal languages, sequences of events, and the surrounding natural conditions [3]. Broadly, the link between the use of languages and the nature in a ritual becomes an undeniable thing. Regional languages, based on their division, can be divided into conversation language and frosen language used in certain rituals. The use of conversation language can be found in our daily activities but the frosen one only can be found in rituals and should not be spoken by just anyone. The one who explain it must have specific criteria to make him proper to recite it, as well as in the Poan Dorong Dopeq migration ritual.

In a sacred ritual like Poan Dorong Dopeq, all the participants must follow all its event sequences. McQuail stated that there are implied messages or special expressions in every communication ritual which become the value of it. What is contained in any language 
rituals, both verbal (spells, poems, songs, ballads, and so on) and non-verbal (symbols, indexes, icons, and so forth) belong to the cultural products and it must be preserved since they are timeless and unchangeable even though the age progresses really well [4].

Haugen's theory disscus languange and ecology, it's related to interaction of traditional language and environment [5]. In the spell of Poan Dorong dopeq, Humans and natures are two important components that are interdependent and interrelated. In everyday life humans need natures to complete their lives and vice versa, natures need humans to look after and maintain their fertility. This interconnected concept is where mutual or mutually beneficial functional relationships are established. For Kedang's people, nature is their backrests of life where people's lives starting from home, eating, and rituals are require natures. Geographical conditions become a full support for why they and their nature become as one.

Human and nature relations also has a correlation with the culture, the spell used in Dorong Dopeq is the product of the culture. So, it can be inferred that the language is the part of the culture. People who study about culture must have a communicative competence and understand the culture relativism. The concept of the culture is a sort of cognitive knowledge that must be understood by people since it has the way of thinking related to people behavior in the daily life. In the other hand, Palmer (Cited from Hellinger) explained about cognitive linguistic and its correlations with the culture, language, people and cultural prism. Cultural prism is about a certain behavior, language used in an ethnic and the exposure meaning of the culture for certain group of people [5].

Based on the explanation above, this journal discusses how Kedang people representing their relations with nature through Poan Dorong Dopeq spell in their migration tradition.

\section{Method}

This journal discusses about the representation of human and nature relations in the spell of Poan Dorong Dopeq in the migration tradition of Kedang people. This spell is recited by molan (shaman) to the tribe that will move. The study of this journal is a descriptive qualitative study; the researcher describes the human and nature relations based on the spell recited by molan. The researcher uses the data gained from Pos Kupang newspaper on Sunday, 24 November 2019 as the secondary data. Besides, the researcher also carried out interview with indigenous people in Kedang by phone on 30 March 2020. Those data is transcribed and translated for each word to sentences. In the translation process, the researcher collaboratively works with Kaharudin Hobamatan and Mursalin Noreng as the native speaker and socially prominent of Kedang.

The data is analyzed by using agih and padan method by Sudaryanto. Padan technique used here is sorting the meaning of each spell word since the spell in the migration tradition is mostly metaphor [6]. First, the data collected by the researcher is transcribed and translated word by word and sentence by sentence. After the translation process, the researcher checks the correctness and the congruity of the meaning in the spell words. The data is then adjusted with the life and the condition of Kedang people. In analyzing the spell, the parsing of description pattern and spell structure is based on Fox's theory [7]. Besides Fox, the theory of langugae and ecology by Haugen also cover dicsussion of spell of poan dorong dopeq in this study.

\section{Result and Discussion}

Here, the researcher describes how Kedang people representing their relations with the nature through Poan Dorong Dopeq spell in migration tradition. This spell is known as 
frosen spell which could not be pronounced by anyone. It could not be found in daily conversation. The following is the result and discussion of this study. In the ritual practice of Kedang people, all the big family of ine ame and kang aring is gathered in the certain place while waiting for the molan to come. After molan is coming, molan will stand in the middle of the big family. All in one circle; there is a stone placed in the middle of the circle as the symbol of their ancestor existence that they believed joining the ritual. The recitation of Poan Dorong Dopeq spell is performed after all of them is sacred, then, it is opened with these following sentences;

$\begin{array}{lll}\text { Loyo no'o elu anaq } & \text { deq noq } \\ \text { Hari ini janji tepat } & \text { sekarang } \\ \text { Today a right promise } & \text { now } \\ \text { Hari ini kami berjanji } & \\ \text { Today we promise } & \end{array}$

wo'elnenun deqnoq

sudah genap now

As a whole

sudah berkumpul semua

We've all gathered

\section{Loeng lereng bitol hewal \\ Sampaikan kami mohon \\ To say we hope \\ Kami sampaikan permohonan \\ We say a hope}

be uhe ria aribara

kepada penguasa besar paling besar

To the almighty Lord the greatest

Kepada saing ghoib penguasa bumi yang agung

To the supernatural ruler of the great earth

$\begin{array}{lllll}\text { Utun } & \text { beq } & \text { udeq sue, Anaq } & \text { beq } & \text { telu apaq, } \\ \text { Small } & \text { PREP } & \text { one, two children } & \text { PREP } & \text { three four }\end{array}$

Keturunan Kami sudah berkembang beranak Pinak

Our descendants have proliferated

Mete hipa kole, Mete behu buel,

Semakin tambah keliling, semakin tambah gerombol

The more circumferential, the more the group

Semakin bertumbuh pesat dan menyebar

Growing and spreading rapidly

In the first spell, molan began with 'Loyo no'o' which means "today", that word is usually used in the spell since it is common. As in death spell "maten wela" which also began with 'Elu oyo' and also means "today". The concept of the word "today" used by Kedang people as an expression of gratitude and a word of salutation, then, it is followed by the word 'elu anaq' means keep the promise. In second sentence, the word 'wo'el nenun' means already fit. When those two sentences is combined, it means "today we all gather and promise" which means a promise to the lord when all the descendants have gathered. In the language of everyday speech, the word lexicon promises to human is 'bele 
elu' but when the concept is in the terms of God then the word used is 'elu anaq, wo'el nenun'. The meaning of the first sentence of the spell as a whole is a dialogue of promises made by molan (shaman) representing all ine ame, kang aring all big family.

The third and the fourth sentence explains about the purpose of all descendants gathering and promising is to asking for a help to the lord of the land. The lexicon shows the lord of the land is indicated with "uhe ria ari baraq" the word 'ria' means big and tall, there is no comparison with any creature. In everyday life, the word 'hewal' is interpreted as a particular traditional celebration, not as wedding, circumcision, or proposal. The mention of those parties is called 'hoeklalek' while bitol hewal is defined as the gathering of all descendants from one ethnic line. Yet, in the concept of Poan dorong Dopeq, the lexicon is interpreted as large hopes.

The fifth sentence tells about the circumstance and the amount of all the tribes consists of children, teenagers, adulteries, and even old people. Its amount getting bigger and they gather altogether to become one big family in a village year by year. If we take a look closely, the spell pattern that says the situation has a unique pattern by mentioning 'Utun beq udeq sue' and 'anaq beq telu apaq', this concept implies that the amount of growth is greater than the natality rate. In Kedang language poetry, mentioning numbers is also using udeq-apaq (one-to-four). For instance, "Aapi kiloq ote ili, aapi kiloq ele sue" the word 'sue' means "two" used in the poem. This is uniquely why other numbers are not used in the poem while number one-to-four are used representing both small and big numbers.

The sixth sentence in the opening spell describes the density of an increasing number of tribes due to growth and natality rates. In Kedang language, there are several lexicons experiencing compounding or a combination of two word's classes which mean as one. On the fifth and sixth sentence of the spell, there are the words 'hipa kole' and 'behu buel' that "multiply" but in different context. Contextually, the word 'hipa kole' means the increasing number of houses around the village and the word 'behu buel' means more and more descendants.

Completely, opening spell reveals the promise of one tribe to God since they are about to migrate Dorong Dopeq to another place. Molan (shaman) tells how a whole people gathered, the number of descendants from children to adults. The beginning of the spell is conveyed as a form of respect to God for all surrounding circumstances and natural situations. After finished with the opening, molan continues the spell recitation with these following sentences;

$\begin{array}{ll}\text { Hipa neq } & \text { namo tehu. } \\ \text { Tumbuh PREP } & \text { subur serumpun } \\ \text { Grow } & \text { fertile cognate } \\ \text { Tumbuh subur serumpun-rumpun } \\ \text { Growing fertile cognate }\end{array}$

Beq moleng

udeq nore kuq

Ada susah satu dengan ambil

There is a sorrow with one taken

Datang susah saling membantu

Once hardness coming, helping each other

Laen udeq mete neq

Sakit satu sambil PREP

Sick one while

Datang duka saling menolong

Once sorrow's coming, helping each other 


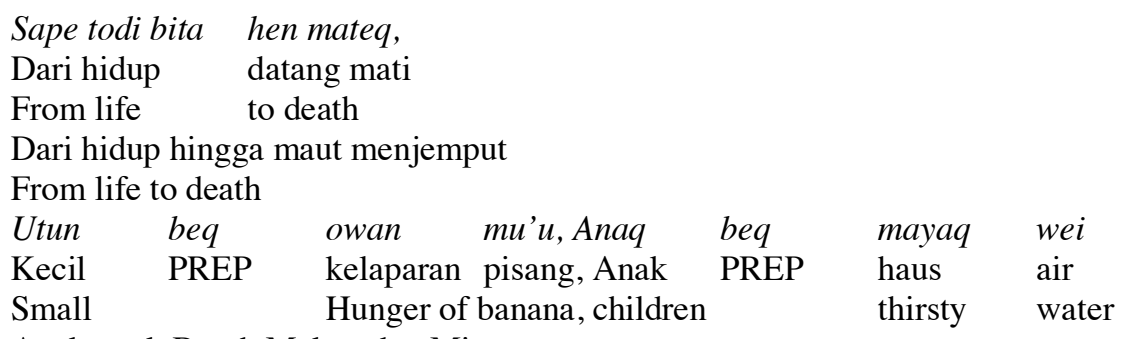

Anak-anak Butuh Makan dan Minum

Children need to eat and drink

\begin{tabular}{llll} 
Mete mo'an & tuaq & beq & mete mayaq, \\
Semakin padat & tuak & PREP & $\begin{array}{c}\text { semakin kering } \\
\text { The more crowded }\end{array}$ \\
Thalm wine & \multicolumn{2}{c}{ drier }
\end{tabular}

Semakin padat lahan usaha semakin sulit

The more crowded the land the harder the business

The second part of Poan Dorong Dopeq spell tells us about the state of distress they have experienced before finally deciding to migrate to find a new location as their residences. The first sentence in the second spell describes the states of the tribe which is increasingly crowded and simultaneously living in one village. Living in one village with the same tribe is the sort of Kedang people's tradition. They do not mingle with other tribes because they take care of their values and ancestry. For instance, in the village of Tiba there are two tribes; Noreng and Lamabawa, both tribes have their own boundaries. Lamabawa people are living near the highway while Noreng tribe is living in a bit indented. The second sentence describes the characteristic of Kedang people, in the sentence "beq moleng udeq nore kuq" which means that if there is one experience distress or sorrow, all people of the tribe should also feel the same. The lexicon used in explaining the brotherhood feeling is " $k u q$ " which means taking and it is adjusted to the cognitive meaning to help each other distress.

If the second sentence is about helping each other distress, the third sentence is about supporting, helping, looking after, and giving a food each other when there is one of the members of the family is sick. It also belongs to the characteristic of Kedang people. If the disease severe, he will be taken to the molan to traditionally cure. It is because they are living in the mountain and far away from any hospital. Some people still believe that if they are sick they will be treated by the nature not the human or the medic. Another characteristic of Kedang people is also defined in the fourth sentence; a faithful, a faithful to live together in one tribe without any division either in the state of joy or sorrow. None of them are leaving their relatives because in tribal regulations, tribal members who left or married with people outside the island (Java, Kalimantan, Sumatera, etc) will be fined.

The last two sentences in the spell describes the situation experienced by tribal descendants that make them must perform dorong dopeq, they have shown their devotion and loyalty to their fellow tribes but the existence of disaster requires them to do dorong dopeq or migration. The fifth sentence shows the general meaning of the situation of children need to eat but the lexicon-based meaning shows that the children is starving of bananas "owan mu' $u$ ". The reason why banana is frequently used in every spell of Kedang people is because their land is geographically overgrown with bananas and their staple food is banana. In every events such as ritual of death (maten wela), migration (dorong dopeq), and wedding parting ( $k u q$ weq) the mandatory food that must be served is banana. 
The last sentence generally shows how crowded the residence is and how hard the economic conditions are, for example is when Noreng tribe had settled for a long time in the area of Tiba then Lamabawa tribe is coming to live there and control the market,Noreng tribe would feel that the lives of their descendants would be a bit threatened. The lexicon in the last sentence of the second spell uses metaphor with the phrase of "tuaq beq mete mayaq" which means the palm wine is getting drier. Palm wine is an alcoholic beverage made from nira tree, enau tree or siwalan. Kedang people have a habit of making a tuaq (wine) for their daily consumption as well as for their traditional events. Similar to banana tuaq is also a must-served beverage in every circumstance. Although Tuaq contains a quite high level of alcohol, it has a function for Kedang people to make their bodies warm and healthy since geographically they live in mountain. Talking back about the expression above, the meaning resulted based on embodied experience of Kedang people is the business they have is getting harder to do since tuaq is getting drier and it causes them to not be able to warm and make their bodies healthier anymore.

Broadly, the second spell describes the characteristic of Kedang people which always helping each other and obeying to the tribal rules. Besides, it also describes how close Kedang people to their surrounding nature, it is expressed with the use of plants as their staple foods; ' $m u$ ' $u$ ' or banana is used to describe the hunger situation and a must-served beverage, tuaq, is used to describe their occupations or businesses. After reciting the second spell, molan continues with the main spell of poan dorong dopeq ritual, the spell is about their prayers to the lord of the nature and it is as follows;
Ma loeng lereng bitol,
Mari kasih tau pemberitahuan
Let's tell announcement
Kami sampaikan permohonan
We submit a request

$\begin{array}{lcll}\text { Be } & O & \text { nimon rian } & \text { arin baraq } \\ \text { Kepada } & \mathrm{Mu} \text { penguasa besar } & \text { paling besar } \\ \text { To } & \text { You the great ruler } & \text { the greatest }\end{array}$

Kepada sang Penguasa Agung

To the great ruler
Ahe toha
mete pan,
Membangun
sambil jalan,
Ola ka
makan
Building
as going along
eating
mete pan
sambil jalan
Sembari Membangun dan mengolah lahan yang baru
as going along
While building and cultivating the new land

$\begin{array}{ll}\text { Paiq min } & \text { mete pan } \\ \text { Menyiram air } & \text { sambil jalan } \\ \text { Irrigating } & \text { as going along }\end{array}$

Sambil mengairi kehidupan baru

While irrigating the new lives

Iher leu mete pan pating auq mete pan,

Buka kampung buka tanah sambil jalan

Open the village, open the land as going along

Sembari membuka kampung halaman yang baru

While opening the new hometown 


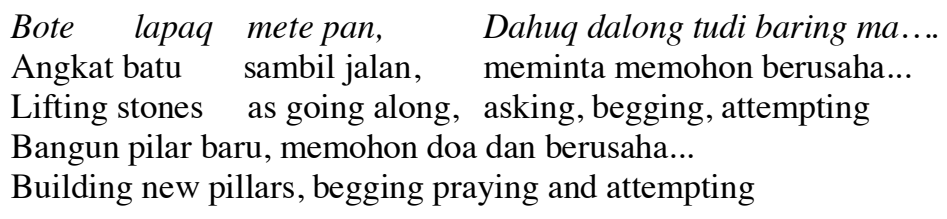

“Nikol udeq kara tikol nadan udeq kara tadan, Waq udeq kara todil ai udeq kara ba'ung "Agar dijauhkan dari segala musibah, bala', ataupun bencana"

Here, Kedang people led by molan tell their intentions to migrate and their promise to build a better life. Their intentions and purposes are explained in the third sentence "ahe toha" which means "to build" and 'ola $k a$ ' which means "to cultivate", the lexicon 'mete pan' is an expression that means continuing. Related to regional development, the region will be always renewed and developed. It also stated in the agreement that they will irrigate their new lives 'paiq min' and build a home 'bote lapaq'. The lexicon 'bote' actually means carrying or lifting and 'lapaq' in the 'bote lapaq' contextually means building a home, then it is continued with 'dahuq dalong tudi baring ma' means praying and attempting.

Then, the last sentence in the praying spell recited by molan represents their expressions of hoping to be kept away from calamities, disasters, or misfortunes. It is in the form of metaphor "waq udeq kara todil ai udeq kara ba'ung" that means "do not throw a single stone and do not break a single wood" based on their experiences "waq" atau stone and "ai" or wood are the symbol of fight and fight means as calamity.

Based on some explanations in advance, Kedang people have a migration tradition and look for the best place to live in, they believe that nature give them all and the Lord must bless them to migrate. Beneath the foothills of the Uyelewun mountain, They are free to choose whenever the place they want to live in, as long as they perform "poan dorong dopeq" ritual for asking permission to the greatest Lord "nimon rian ariq baraq". After conveying their intentions, molan (shaman), tuan huna (tribal chief) and all their tribal relatives continue to have ka mema' or eating out. There, the menu served is varied; lamb, pork, vegetables and various mandatory drinks and menu that must be served like $т и$ ' $u$ or banana, ai loloq motong (marungga), and tuaq or palm wine.

After finished with $\mathrm{ka}$ mema', all tribal members and of course the molan recite a poetry accompanied by Kedang traditional music; gong. Gong is hit by several youth tribal along with potluck dance as an expression of happiness since they are about to migrate to the new place and start new lives, and to be kept away from disasters. The poetry is as follows;

Lalang amo lalang, apan kappa mete pan,

Agar tandai kami menjalar tumbuh berkembang

So mark us spreading up to develop

Tuan woq boiq laha, Ke leteq huna paheng ahar

Mohon restu wahai arwah leluhur, kami bangun rumah tanam dasar

Please blessing us, $\mathrm{O}$ ancestor, we build planting house bases

Bota wo bota,

Restu penguasa bumi,

Blessing of the lord of the earth 
Lei toreng doq oleq,

Kaki melangkah pergi kebawah

Foot is stepping down

Inaq bote lapa

Ibu menggendong pilar

Mother is carriying the pillar

Mahuq auq bote lapaq".

Angkut tanah gendong pilar."

Lifting the soil carriying the pillar

In the closing of the poetry, all is saying prayers and hope, all of tribal members is requesting the Lord's blessing to ease their migration process. The first line of the poetry is an expression of Kedang people's hope and goal; it is began with "Lalang amo Lalang". The word "Lalang" is the name of one of the Lord, it is followed by the word "apan kappa" which means spreading up to develop is indicated that the tribal hope on their migration so they can later be success and develop their new places. The second line is "Tuan woq boiq laha, Ke leteq huna paheng ahar" which implicitly means "Only the Lord has it all, we build a root house bases". The implicit meaning is showed with the lexicon "paheng ahar" which means "planting root"; building houses from the base. This is in line with the concept of tree where the root is the base of trunks, branches, leafs, and all its components. At that time, to build a house, Kedang people used wood of coconut, jackfruit, or teak tree as the foundation and using bamboo as its wall, dried coconut leafs as its roof, so because of those things, "paheng ahar" is used in the migration ritual poetry. The following sentence is "Bota wo bota" invocation to call the name of the Lord; there several names are sacred according to Kedang people such as Bota, Lalang, Ena, Muko, Puen, and etc. The names used in the spell are intended for begging bless to the Lord since it is highly polite to do so. Afterwards, it is continued with saying their purposes with the sentence of "lei toreng doq oleq" which means foot is stepping down to migrate. This line has the meaning that is appropriate with the nature and geographic aspects of Kedang's region where the people, at first, living in the mountain slope and moving to the lower and lower places, opening new lands, and living in new place that is not too close to the mountain. Those are indicated in the lexicon "doq oleq".

The two last sentences in the poetry also explained Kedang people's goal, building a new tribe in a new place. There is "Ina bote Lapaq" which means mothers carry the pillar, it has connotative meaning where mother depicts as the key where the life is started. Then, it is closed with the sentence "mahuq auq bote lapaq" which means lifting the land carrying the pillar. This sentence is not literally interpreted as lifting the land to be brought to or moved to but it is connotatively means when we move or migrate, all descendants are leaving and carrying all the old lives to again build a new life in a new place "bote lapaq". The concept in "auq" or land or soil for Kedang people is like a hometown that must be loved since they believed that is also the component or part of themselves. The above poetry can be inferred that a migration of a group of people must be blessed by the Lord and have to promise to build a proper life for all descendants.

\section{Conclusion}


Knowing the human and nature relations in a migration ritual spell shows us that we as human being need nature. Kedang people who live in the foothills of Uyelewun mountain have a million ways to appreciate the nature itself, one of it is by performing poan dorong dopeq. Poan dorong dopeq spell explains to us that Kedang people appreciate the nature and its components. The tribe that will migrate need to asking permission to the lord and tuan huna for promising onto the Lord to create a proper life, opening irrigation, and start doing business to put their descendants on welfare. Some expressions of respects are recited to the Lord by calling his names so their goals and intentions can be sent well. Some spell sentences are also given in the form of metaphor and embodied experience of Kedang people, for instances, "owan mu'u” or hunger of banana and "mete moan tuaq beq mete mayaq" or tuaq (palm wine) is getting drier. All spell expressions are related to the situations, nature concepts, and geographic aspects of Kedang people.

\section{References}

1. Y.D. Manafe. Komunikasi ritual pada budaya bertani Antoni Pah Meto di Timor Nusa Tenggara Timur. J. K 1.3 (2011)

2. P. I. Nindatu. S. S. M.H. S.A. Pemaknaan Ritual Budi Daya Padi Ladang Sahu Jio Tala'i Padudua. J. P 19. 2 (2018)

3. Mulyana. Ilmu Komunikasi suatu Pengantar. Bandung Remaja. Rosdakarya (2005)

4. D. McQuail. McQuail Mass Comunication Theory. London Sage Publication (2000)

5. M. Hellinger. A. P. Handbook of Languge and Communication:Diversity and Change. Mouton de Gruyter. (2007)

6. Sudaryanto. Metode dan Teknik Analisis Bahasa. Yogyakarta. Sanata Dharma University Press. (2015)

7. J. F. Fox. To Speak in Pairs. New York. New Rochhelle. Meulbourne. Sydney. Cambridge University Press (1998) 